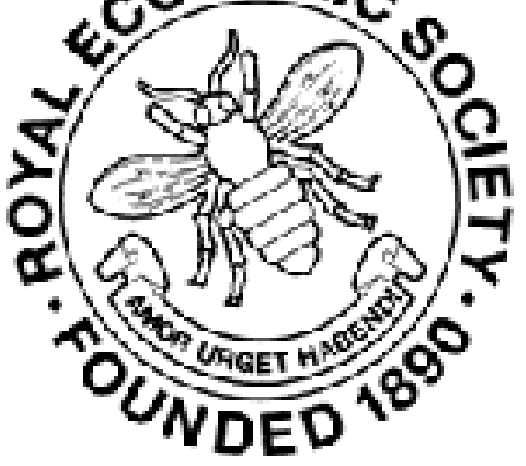

\title{
WILEY
}

\section{The Financial Situation in Russia}

\section{Author(s): Arthur Raffalovich}

Source: The Economic Journal, Vol. 14, No. 56 (Dec., 1904), pp. 625-632

Published by: Wiley on behalf of the Royal Economic Society

Stable URL: http://www.jstor.org/stable/2221268

Accessed: 27-06-2016 04:15 UTC

Your use of the JSTOR archive indicates your acceptance of the Terms \& Conditions of Use, available at

http://about.jstor.org/terms

JSTOR is a not-for-profit service that helps scholars, researchers, and students discover, use, and build upon a wide range of content in a trusted digital archive. We use information technology and tools to increase productivity and facilitate new forms of scholarship. For more information about JSTOR, please contact support@jstor.org.

Royal Economic Society, Wiley are collaborating with JSTOR to digitize, preserve and extend access to The Economic Journal 
Between the findings of the Tariff Commissioners upon the comparative state of the British iron and steel industry and their suggested remedies there lies a chasm which they do not try to bridge. To many convinced Protectionists there is a logical connection between the two, but no such logical connection exists in the minds of Free Traders and certain others who would admit Protection under many circumstances which the Free Trader would not regard as necessitating Protection. Many will be found to argue that, taking the results of the analysis of present conditions by the Tariff Commissioners as correct, a heavy balance of loss, in which the Colonies would share, would be the result of imposing the suggested tariffs.

\section{S. J. Chapman}

\section{The Financial Situation in Russia}

PoLITICAL dissensions between one nation and another are un. fortunately liable to be attended by a lack of clearness of vision, and are apt to foster unjust prejudices concerning matters of fact. Twenty-eight years ago the present writer was drawn into a controversy with some English journalists in connection with the question of Russian solvency. It was on the eve of the war against Turkey for the enfranchisement of Bulgaria. As the result of a conservative policy, $M$. de Reutern had succeeded in restoring financial soundness, which had been shaken by the Crimean War, and in throwing a network of railways over the country, but had not been able to attack the monetary evil-that of the paper money.

When the war broke out in 1877 it found Russia with a cash reserve of only $180,000,000$ roubles, against which there were to be issued 450,000,000 roubles of paper money (temporary credit notes) constituting a Government debt to the Bank of Russia, bearing no interest. Under very onerous conditions the Government raised internal loans of $800,000,000$ roubles, and one foreign loan of 15,000,000 pounds sterling in Paris and Berlin, all at 5 per cent.

The temporary credit notes disappeared many years ago. Five per cent. bonds have been converted into 4 per cents., that is, 3.80 per cent. net for all internal loans subject to income-tax. 
And, instead of a reserve of $180,000,000$ roubles, guaranteeing nearly $1,200,000,000$ roubles of bank notes, we find a credit reserve in gold of gigantic amount, exceeding the united reserves of the Banks of England, Germany, and Italy. The interest on the national debt and its redemption, far from occupying the large proportion of the Budget obtaining twenty years ago, amounted in 1897 only to $19 \cdot 60$, in 1901 only to $16 \cdot 61$, in 1903 only to 15 per cent.

After the war with Turkey, that is to say, from 1880 onward, it was necessary to liquidate the cost of the war, re-equip military stores, and set on foot fiscal reforms, in the midst of deficits and deficient crops. During his brief ministry M. Abasa paved the way for withdrawing the paper circulation issued during the war, and had the courage to abolish the salt tax. M. Bunge removed the poll tax, lightened the burdens of the peasants, created the income-tax on movable property (except on such loans as were guaranteed exempt), and improved the organisation of the Budget. M. Wischnegradski began his great conversions of the national debt, and fostered the formation of a gold reserve, so indispensable to monetary reform and to the resumption of specie payment. M. Witte, in the eleven years of his ministry, completed the work of conversion, carried out the reform of the coinage, endowed the State with a monopoly in the sale of alcohol, organised the State railways - which to-day include two-thirds of the Russian railroads-supplied the means for constructing the Trans-Siberian line, and, thanks to the system of setting aside a reserve against times of emergency, put his successors in a position to offer Russia as a send-off, on the day when the Japanese took the offensive, $310,000,000$ roubles.

I have brought forward this collection of historical facts in the conviction that, in order to a sound judgment on the finances of any country, it is necessary to know the antecedents of any given situation. There is no field in which the nexus of facts is a surer guide and in which the general situation is more faithfully reflected than that of the data revealed by the national Budget.

During the twenty-seven or twenty-eight years which I have been considering, how many prophecies of the inevitable bankruptcy of Russia have events proved false! Bears on the Stock Exchange in 1877-78, officious German newspapers in 1887, City journals time and again, have vented their spleen without result. The bases of the national finance of Russia have been broadened, and our creditors can rest assured. We could double the annual amount of the annuity for the public debt before touching the 
limit deemed to be dangerous for a State's creditors, such as may be held to come between 33 and 40 per cent. of the annual Budget. Not with a light heart has Russia gone to war, but, once having let herself go, she regards herself as the champion for continental Europe; and hers, too, is the firm and implacable determination of going on to the uttermost.

" Russia, up to the very moment of rupture, was working imperturbably at the progressive consolidation of her finances. Even in years of industrial crises and defective harvest her foreign trade showed an excess of exports over imports more than sufficient to compensate payments sent abroad. And, as guarantee of her monetary system, she has succeeded in amassing and maintaining a vast reserve of gold." Such are the terms in which M. Helfferich, Professor at the University of Berlin, and one of the best pupils of Ludwig Bamberger, appraises our financial position.

It would be easy to adduce analogous opinions from well-known French authorities to corroborate the estimate pronounced by Professor Helfferich; for example, that of M. Paul Leroy Beaulieu, editor of $L^{\prime}$ Économiste français. ${ }^{1}$

Sound finance is not a thing that may be improvised. It is the work of constant and sustained effort. Such has been the work especially of men like Bunge, Wischnegradski, and Witte, thanks to whom the present Minister of Finance has been able to cope with the formidable demands of the war against Japan.

Before giving any figures relating to the Budget for the present year and to the war, I must point out that from 1893 to 1902 the sum of the ordinary revenue had been $15,116,000,000$ roubles, the expenditure $13,544,000,000$ roubles, leaving an aggregate surplus of $1,572,000,000$. Thanks to this surplus we have been able to cover over half of our extraordinary expenses. These have absorbed $2,609,000,000$, from which were taken the amounts required for the sinking fund to repay the public debt to the Bank of Russia, for the relief fund devoted to districts affected by agrarian distress, to advances made to railway companies, and to the Boxer war. Since 1894, when the objects to be put into the extraordinary Budget were defined by a new Act, many expenses included under this head by other nations have also been incorporated with the ordinary Budget by us, e.g. army and navy supplies, and maintenance of railway rolling stock. From 1891

1 See the Marine Rundschau for October, 1904, Karl Helfferich, wirklicher Legationsrath: "Die finanzielle Seite des russisch-japanesischen Krieges," or the French translation published at Guillaumin's. 
to 1904 Russia has, thanks to her surplus on the ordinary Budget, constructed 9,375 miles of railroads, thus heightening the Imperial value of Siberia and Central Asia. And it is the ordinary Budget which has covered the expenses of putting into execution the liquor reform (the monopoly of the sale of brandy).

The State purchase of railways, with the issue of State bonds in place of the shares of private companies, the conversions, and the redemption of the debt arising from fiduciary circulation, have brought about a profound alteration in the components of the Russian national debt. Through these transactions (railway purchase, resumption of specie payment, and increase of nominal capital of converted loans), the total has risen from 4,992,000,000 roubles in 1889 to $6,643,000,000$ in 1903 . On the other hand, railway capital, which in 1889 was $1,363,000,000$ roubles, in 1903 amounted to $3,629,000,000$. Hence, properly speaking, the debt has been reduced from $3,629,000,000$ to $3,444,000,000$.

The following comparison is also instructive :-

\begin{tabular}{llcc} 
& & $\begin{array}{c}1892 . \\
\text { (In millions of roubles.) }\end{array}$ \\
Nominal amount of interest-bearing debt & $\ldots \ldots .$. & 4,731 & 6,479 \\
Debt bearing no interest (paper money) & $\ldots \ldots \ldots . .$. & 637 & \\
\hline & & 5,368 & 6,479
\end{tabular}

Against these figures we must place the Government assets :-

\begin{tabular}{|c|c|c|}
\hline Railways... & 950 & 3,551 \\
\hline Capital owed to the State by railway companies .......... & 984 & 563 \\
\hline $\begin{array}{l}\text { Advance by the State on account of interest guaranteed } \\
\text { to railway companies } \ldots \ldots \ldots \ldots \ldots \ldots \ldots \ldots \ldots \ldots \ldots \ldots \ldots\end{array}$ & 118 & \\
\hline Advances having no connection with railways........... & 309 & 5( \\
\hline
\end{tabular}

In the assets no inclusion has been made of State forests, the produce of which is increasing, nor of factories or foundries, nor of the capitalisation of the redeemable peasant annuities.

The interest on the national debt was covered, in 1903, as far as two-thirds by resources which were not yielded by taxation, but by the net profit from railways, deposits from railway companies, net profits from Government loans.

For 1904 the ordinary revenue was estimated at 1,980,100,000 roubles, the ordinary expenditure at 1,966,500,000, giving a surplus of $13,600,000$. The revenue in the extraordinary Budget was $198,600,000$ (of which $195,800,000$ were to be taken from 
Treasury funds), and the expenditure $212,200,000$. The surplus on the ordinary Budget covered the difference. It has been a rule with Russian Ministers to maintain the disposable Treasury funds at a considerable minimum, using for this the surplus on the ordinary Budget, which, between 1893 and 1902, have realised an average of $150,000,000$ roubles a year, and also produce of loans. ${ }^{1}$

Among the extraordinary expenses were $125,000,000$ roubles spent on railway works and $63,000,000$ more on loans to companies. In the ordinary Budget the Crown dues (including the alcohol monopoly) were reckoned at $590,000,000$, and the produce of the State domains, including railways, at 560,000,000. Thus more than one-half of the ordinary revenue is derived from sources other than taxation. This leaves 135,000,000 for direct taxation, 421,000,000 for indirect taxation (customs, tobacco, sugar, excise on petroleum), and 103,000,000 for rights and dues (including stamps).

Following Professor Karl Helfferich, I give the summing up of the Russian Budget in millions of roubles, as under :-

$\begin{array}{cccccc} & & \text { Revenue. } & \text { Expenditure. } & \text { Deficit. } & \text { Surplus. } \\ 1883 & \ldots \ldots \ldots \ldots . . & 700 \cdot 4 & 723 \cdot 6 & 23 \cdot 2 & - \\ 1887 & \ldots \ldots \ldots \ldots . & 820 \cdot 4 & 892 & 21 \cdot 6 & - \\ 1888 & \ldots \ldots \ldots \ldots . & 873 \cdot 6 & 837 & - & 36 \cdot 6 \\ 1892 & \ldots \ldots \ldots \ldots . & 964 \cdot 7 & 952 \cdot 6 & - & 12 \cdot 1 \\ 1897 & \ldots \ldots \ldots \ldots . & 1416 \cdot 7 & 1229 & - & 187 \cdot 7 \\ 1902 & \ldots \ldots \ldots \ldots . & 1905 \cdot 4 & 1665 \cdot 4 & - & 250 \\ 1903 & \ldots \ldots \ldots \ldots . & 2032 \cdot 5 & 1722 \cdot 9 & - & 309 \cdot 6\end{array}$

From 1883 to 1903 expenditure increased 250 per cent., and ordinary revenue 300 per cent. This increase is largely due to the inclusion in the Budget of monopoly expenses, of State railway expenses, and to enlarged army and navy supplies. Expenditure in connection with the debt has gone up very little, thanks to the conversions. The following shows the percentages in the total expenditure of ordinary expenses in 1897 and 1901 :-

\begin{tabular}{|c|c|c|}
\hline & 1897. & 1901. \\
\hline National Debt ....................... & $19 \cdot 60$ & $16 \cdot 61$ \\
\hline Army and Navy ... & $28 \cdot 16$ & $25 \cdot 69$ \\
\hline 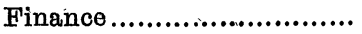 & $15 \cdot 20$ & $18 \cdot 52$ \\
\hline Agriculture ..................... & $2 \cdot 50$ & $2 \cdot 47$ \\
\hline Education ....................... & 1.99 & $2 \cdot 01$ \\
\hline (....................... & $19 \cdot 67$ & $23 \cdot 34$ \\
\hline Remainder & $7 \cdot 88$ & $11 \cdot 36$ \\
\hline
\end{tabular}

1 According to M. Kergall's mot, Russia, a poor country, needs a rich Budget, i.e., amply based and furnished with reserves.

No. 56.-VOL. XIV.

U U 
One of the most useful works in Russia, of which she retains the entire profits, has been that of monetary reform. This is shown by the appended table (in millions of roubles) :-

\begin{tabular}{|c|c|c|c|}
\hline & $\begin{array}{l}\text { Credit notes } \\
\text { issued and in } \\
\text { circulation. }\end{array}$ & $\begin{array}{l}\text { Gold reserve } \\
\text { in Bank } \\
\text { and Treasury. }\end{array}$ & $\begin{array}{c}\text { Gold } \\
\text { circulation } \\
\text { in Russia. }\end{array}$ \\
\hline $1881 \ldots \ldots \ldots \ldots \ldots \ldots$ & $\ldots \quad 1133 \cdot 5$ & 170 & - \\
\hline 1887 ................... & ... 1046 & 211 & - \\
\hline $1892 \ldots . . \ldots \ldots \ldots \ldots$ & ... 1100 & 905 & - \\
\hline $1898 \ldots \ldots \ldots \ldots \ldots \ldots$ & 905 & 1328 & 149 \\
\hline $1900 \ldots \ldots \ldots \ldots \ldots$ & 552 & 807 & 684 \\
\hline $1903 \ldots \ldots \ldots \ldots \ldots \ldots$ & 584 & 1058 & 787 \\
\hline
\end{tabular}

The right of the Bank of Russia to issue notes is regulated with a view to the maintenance of the gold standard. So long as the value of the bank notes in circulation does not exceed $600,000,000$ roubles, the gold reserve should not be less than onehalf the sum represented by the notes issued. Above $600,000,000$ the notes ought to be covered by gold, rouble by rouble. ${ }^{1}$

Finally, to show the bases of Russian finance, I give some data on the foreign commerce of the Empire.

\begin{tabular}{ccccc} 
& \multicolumn{2}{c}{ Imports. } & $\begin{array}{c}\text { Exports. } \\
\text { Excess of Exports. } \\
\text { (In millions of roubles.) }\end{array}$ \\
$1885 \ldots \ldots \ldots \ldots$. & $435 \cdot 3$ & $538 \cdot 6$ & $103 \cdot 3$ \\
$1895 \ldots \ldots \ldots \ldots$. & $489 \cdot 4$ & 591 & $201 \cdot 6$ \\
$1901 \ldots \ldots \ldots \ldots$. & 533 & 730 & 197 \\
1902 & $\ldots \ldots \ldots \ldots \ldots$ & 527 & 825 & 298 \\
$1903 \ldots \ldots \ldots \ldots$. & 601 & 949 & 348
\end{tabular}

From these figures the conclusion may be drawn that Russia has sufficient economic strength to maintain her finances and her money in a normal and regular condition. ${ }^{2}$

To cope with the demand created by the war, Russia has reduced her expenditure, both ordinary and extraordinary, by $134 \frac{1}{3}$ million roubles, 54 millions of which are withdrawn from the construction of new railways. Through these retrenchments she has raised her disposable balance to $266,000,000$. Various accretions had already enlarged it so much-notably the plus values in the early part of 1904-that the total disposable funds almost attain the figure of $310,000,000$.

1 Between the 1st and 14th September, 1904, the Bank of Russia had enough gold to cover all the notes issued and all public credit accounts.

2 When the Japanese judged it the right moment to begin the war, Russia was, financially and economically, in a better position than she had ever been. There was more gold than paper in circulation. Two good harvests, 1902 and 1903, had brought about an excess of exports of 640 millions. The railways of the State, the alcohol monopoly, had yielded considerable sums. The funds at the disposal of the Treasury had attained the highest figure ever reached. 
Besides this, Russia has raised most successfully a loan in Paris of $300,000,000$ roubles in Treasury-bonds at 5 per cent. for five years, which the continental investors have accepted at 99 per cent. A loan has also been negotiated in Russia of $150,000,000$ roubles of Treasury-bonds at 3.60 per cent. for five years. The capital of the national debt has increased 4 per cent. The resources provided by the two loans were collected in a spirit of precaution against future emergencies.

There has been no question of falling back into the course taken in 1877-78, and making shift with the handy method of a fiduciary issue. It has not been held desirable to cope with extraordinary expenditure by the sole weapon of the normal elasticity of a paper circulation. Prudence has made it a duty not to risk the safety of a monetary system, organised with so much labour, and on which depends the economic and financial well-being of the country.

In this connection the following figures are instructive :-

\begin{tabular}{|c|c|c|c|c|}
\hline & $\begin{array}{l}\text { Gold } \\
\text { abroad. }\end{array}$ & $\begin{array}{l}\text { Bills on } \\
\text { foreign countries. } \\
\text { (In millions }\end{array}$ & $\begin{array}{l}\text { Gold at } \\
\text { the Bank. } \\
\text { of roubles.) }\end{array}$ & $\begin{array}{l}\text { Notes in } \\
\text { circulation. }\end{array}$ \\
\hline January ................ & 166 & $8 \cdot 2$ & 733 & 578 \\
\hline February ........... & 175 & $2 \cdot 7$ & $745 \cdot 7$ & 598 \\
\hline March................... & 133 & $3 \cdot 1$ & $762 \cdot 7$ & 628 \\
\hline April ................... & 74 & 7 & 771.5 & 634 \\
\hline May ................. & 40 & $6 \cdot 7$ & $803 \cdot 4$ & 648 \\
\hline June & 91 & $4 \cdot 6$ & $821 \cdot 9$ & 665 \\
\hline July ................... & 99 & $1 \cdot 8$ & $838 \cdot 8$ & 689 \\
\hline August ................. & 84 & $1 \cdot 8$ & $863 \cdot 5$ & 695 \\
\hline
\end{tabular}

The stock of gold has increased concurrently with the fiduciary circulation. $^{1}$

On August 1st, 1904, the Bank of Russia could have circulated, over and above this, 553,000,000 roubles in credit notes, in accordance with its charter. It is evident that the Government has well husbanded this withheld reserve.

What are the expenses of the war? Up to August 16th the sources of credit open to all the departments of the Government for the purpose of the war had risen to $257 \frac{1}{2}$ million roubles for more than six months and a half. ${ }^{2}$

According to the Bulletin de Statistique Russe, the cost of the war will amount to $500,000,000$ at least, and to 600 at most, for the current year. And, probably, thanks to the surplus in the

1 The Treasury, besides the Bank reserve and sums owed to it abroad, held in September $272,000,000$ in gold or in foreign securities.

2 According to the official announcement of April 5th to 18th. 
ordinary Budget, the net deficit will amount to no more than $450,000,000$ roubles. This is a long way from the milliards on which Russia's enemies are counting.

War is a cruel test for any nation, but Russia has, a constitution capable of surviving that into which Japan has rushed her. While soldiers and officers are shedding their blood for their country, Russia labours and brings forth accumulating treasures to repair the harm wrought by a distant war. Russia has conquered distance, and the railroad which unites the heart of the Empire to the shores of the Pacific, and is a monument to her energy and her daring, has rendered the greatest services, whatever the habitual detractors of Russia's economic progress may say. From the financial point of view, from the point of view of means of transport, the war has not taken Russia unawares. She was excellently prepared, and, through the superiority of her financial machinery, she can calmly contemplate the prolongation of the campaign.

\section{ARTHUR RAFFALOVICH.}

Note.-The stability of the Russian Exchange is a proof that the monetary reform is a sound piece of work. The absence of fluctuation in Russian bonds proves that there has been little selling out among bondholders. Russian bonds rank exceedingly well in France, Holland, Belgium, and in Russia itself. Russian credit is unimpaired.

In 1903, the alcohol monopoly (sale by the State) has yielded 541 million roubles, the expenses have been 153 millions, the net produce 388 millions. There were 28,247 shops against 28,418 in 1902 . The State receives 112 million roubles more since the introduction of the monopoly.

\section{Recent Official Papers}

Report of the Interdepartmental Committee on Physical Deterioration. Vol. I. Report and Appendix. ... [ [C $\mathrm{C}^{\mathrm{d}}$ 2,175.]

THERE is no statistical evidence of variation in the national physique; but the Committee are able to diagnose and prescribe for certain kinds of deterioration. Among the Appendices are a memorandum by Miss A. M. Anderson on employment of mothers in factories and workshops, and infant mortality statistics for urban and rural counties.

J. F. W. TAthaM 